\title{
A scientific basis to determine the best paliative treatment for malignant pleural effusion
}

\author{
A Hojski , A Crnjac \\ From 23rd World Congress of the World Society of Cardio-Thoracic Surgeons \\ Split, Croatia. 12-15 September 2013
}

\section{Background}

The purpose of our study is to determine the role of growth factors (GF) in the process of pleurodesis. Biochemical characteristics of the pleural effusion (PE) are an important prognostic factor. Published data on the role of GF in the formation of PE and its treatment is somewhat contradictory.

\section{Methods}

A prospective randomized study included 40 female patients with malignant PE resulting from breast carcinoma. They were divided into two groups and treated by means of mechanical (MP) or chemical (CP) pleurodesis. Samples of pleural fluid were analyzed by ELISA. The study was approved by the National Ethics Committee.

\section{Results}

We found a 2.5 times increase in VEGF levels in the serum when performing a $\mathrm{CP}$ and a less than $25 \%$ increase of its original value in MP group. The average serum level of VEGF before receiving CP was $458.65 \mathrm{ng} / \mathrm{ml}(172-702 \mathrm{ng} / \mathrm{ml})$ and was elevated to a mean level of $1197.65 \mathrm{ng} / \mathrm{ml}(406-2011 \mathrm{ng} / \mathrm{ml})$. In the MP group same results for serum VEGF were found $517.55 \mathrm{ng} / \mathrm{ml}(73-976 \mathrm{ng} / \mathrm{ml})$ and $632.24 \mathrm{ng} / \mathrm{ml}(111$ $1136 \mathrm{ng} / \mathrm{ml})$. Peak levels were noted between 24 and 48 hours after performing pleurodesis.

Of the GF secreted, particularly VEGF was present in excess. Serum VEGF could be the cause of some of the side effects we are faced with when performing $\mathrm{CP}$.

The relationship between the released GF in MP is somewhat different. Namely, it has less influence on serum VEGF levels. We also believe that a proteoglycan

\footnotetext{
* Correspondence: aljaz.hojski@ukc-mb.si

Department of Thoracic Surgery, Division of Surgery, University Medical
} Centre Maribor, Maribor, Slovenia

(C) 2013 Hojski and Crnjac; licensee BioMed Central Ltd. This is an Open Access article distributed under the terms of the Creative Commons Attribution License (http://creativecommons.org/licenses/by/2.0), which permits unrestricted use, distribution, and reproduction in any medium, provided the original work is properly cited.

\section{and take full advantage of:}

- Convenient online submission

- Thorough peer review

- No space constraints or color figure charges

- Immediate publication on acceptance

- Inclusion in PubMed, CAS, Scopus and Google Scholar

- Research which is freely available for redistribution Submit your manuscript at
www.biomedcentral.com/submit C Biomed Central 